\title{
Correlation Study between Some Agronomic Characteristics of Plant Crop of Some American Wild Cane under Egyptian Conditions
}

\author{
Gaber, A.A. and M.F. Abo El-Fatth ${ }^{1}$
}

\begin{abstract}
A complete randomized block experiment with three replications was carried out in El-Sabahia Agricultural Research Station at Alexandria to evaluate some American wild cane varieties during $\mathbf{2 0 0 5 / 2 0 0 6}$ season. The wild cane varieties were Hinds Special, S.E.S.90, Saccharum spontaneum and U.S.57-118-4. Ten stalks were chopped at random from each plot after topping at the end of flowering to study the relationship between stalk length and width; tillers number; internodes length, number; leaf length, width, number and total soluble solids.

The studied traits differed with the variation of varieties. The correlations between the studied criteria were positive, significant and highly significant in some traits i.e. and were not significant in other traits i.e. However, the correlations between any two of the four varieties were positive, significant and highly significant in the most studied characters.
\end{abstract}

\section{INTRODUCTION}

Raw sugar produced in over 69 countries through the temperate and tropical regions (Anon, 1959).

Cane sugar is one of the first tropical crops to be adapted to large-scale farming. Since, 1900 cane agriculture has made unique contributions to tropical production. The production of sugarcane is an indicator of different factors as using wild varieties for crossing with noble canes to improve yield of these varieties, and their resistance for diseases and pests.

In Egypt, the gap between production $(1,772,000$ tons) and consumption $(2,600,000$ tons) was $(828,000$ tons). The ratio of self sufficient amounted by $68 \%$.

The present work was conducted to study the level of correlations between agronomical characteristics for wild cane to use them in the breeding programme to improve sugarcane varieties associated with high yield, which is supposed to be useful in cane breeding programmes.

\section{MATERIAL AND METHODS}

A complete randomized block experiment with three replications was conducted in El-Sabahia Agricultural Research Station at Alexandria to evaluate some American wild cane varieties during 2005/2006 season. The wild cane varieties were Hinds Special, S.E.S.90, Saccharum spontaneum and U.S.57-118-4. Ten stalks were chopped at random from each plot after

${ }^{1}$ Sugar Crops Research Institute, Agriculture Research Centre,

Giza, Egypt

Received April 15, 2009, Accepted June17, 2009 topping at the end of flowering and data recorded were as follows:

1-Stalk length was measured as the distance between the top and the base of stalk.

2-Stalk diameters was measured in the middle part of the stalk.

3-Tillers number.

4-Internodes number stalk.

5-Leaf length was measured by stripeline.

6-Leaf width was measured by stripeline.

7-Leaf number

8-Total soluble solids.

Each variety was sown in two ridges, 5 meters length and $1.25 \mathrm{~m}$ width by one and half row method at the end of March in 2005/2006 season. Plot area was $12.50 \mathrm{~m}^{2}(2.5 \times 5.0 \mathrm{~m})$. Rate of nitrogen fertilizer used was $40 \mathrm{~kg}$ per feddan. Irrigation was done 10-15 days intervals with the exception of August and September was 3-5 days intervals. All the other cultural practices were carried out as usual.

The correlation coefficient were calculated between stalk length and diameter, tillers number, internodes number, leaf length, leaf width, leaf number and total soluble solids as described by Snedecor and Cochran, 1971. Means and ranges of the studied criteria were calculated.

The temperature degrees and relative humidity were recorded from Monthly Agricultural Meteorology from 2005 to 2006 seasons, Agriculture Research Centre, Giza, Egypt.

\section{RESULTS AND DISCUSSION}

Table (1) shows means and ranges of stalk length, width; tillers number; internodes length and number; leaf length, width and number; and total soluble solids of the varieties of wild cane, Hinds Special, S.E.S.90, Saccharum spontaneum and U.S.57-118-4, respectively for 2005/2006 season.

Generally, Hinds special and S.E.S.90 were the highest and the lowest mean in stalk length and width in the most studied characters. However, Hinds Special and Saccharum spontaneum were the highest and lowest 
Table 1. Mean and ranges of some economical characters of stalks of plant crop of four American wild cane varieties in $2005 / 2006$ season at El-Sabahia Research Station near, Alexandria, Egypt

\begin{tabular}{|c|c|c|c|c|c|}
\hline \multirow[b]{2}{*}{ Characters } & & \multicolumn{4}{|c|}{ Wild varieties } \\
\hline & & $\begin{array}{c}\text { Hinds } \\
\text { Special }\end{array}$ & S.E.S.90 & $\begin{array}{c}\text { Saccharum } \\
\text { spontaneum }\end{array}$ & U.S.57-118-4 \\
\hline \multirow{3}{*}{ Stalk length $\mathrm{cm}$. } & Mean & 238.00 & 142.00 & 150.70 & 182.00 \\
\hline & \multirow{2}{*}{ Range } & 30 & 10.00 & 10.00 & 45.00 \\
\hline & & $220-250$ & $135-145$ & $145-155$ & $165-210$ \\
\hline \multirow{3}{*}{ Stalk width $\mathrm{cm}$. } & Mean & 2.46 & 0.65 & 0.72 & 0.99 \\
\hline & \multirow{2}{*}{ Range } & 0.30 & 0.10 & 0.10 & 0.10 \\
\hline & & $2.30-2.60$ & $0.6-0.7$ & $0.7-0.8$ & $0.8-1.0$ \\
\hline \multirow{3}{*}{ Tillers No. } & Mean & - & 58.00 & 63.10 & 63.70 \\
\hline & \multirow{2}{*}{ Range } & - & 25.00 & 6.00 & 40.00 \\
\hline & & - & $45-70$ & $60-66$ & 40.80 \\
\hline \multirow{3}{*}{ Internodes length $\mathrm{cm}$. } & Mean & 23.70 & 13.70 & 9,80 & 13.00 \\
\hline & \multirow{2}{*}{ Range } & 3.00 & 3.00 & 2.00 & 2.00 \\
\hline & & $22-25$ & $12-15$ & $9-11$ & $12-14$ \\
\hline \multirow{3}{*}{ Internodes No. } & Mean & 20.30 & 12.00 & 13.20 & 13.20 \\
\hline & \multirow{2}{*}{ Range } & 2.00 & 3.00 & 2.00 & 2.00 \\
\hline & & $19-21$ & $11.0-14.0$ & $12-14$ & $12-14$ \\
\hline \multirow{3}{*}{ Leaf length $\mathrm{cm}$. } & Mean & 190.50 & 127.00 & 120.90 & 100.00 \\
\hline & \multirow{2}{*}{ Range } & 10.00 & 10.00 & 3.00 & 60.00 \\
\hline & & $185-195$ & $120-130$ & $120-123$ & $70-130$ \\
\hline \multirow{3}{*}{ Leaf width $\mathrm{cm}$. } & Mean & 4.11 & 0.64 & 1.07 & 0.049 \\
\hline & \multirow{2}{*}{ Range } & 0.30 & 0.30 & 0.40 & 0.30 \\
\hline & & $4.0-4.3$ & $0.5-0.8$ & $0.9-1.3$ & $0.4-0.7$ \\
\hline \multirow{3}{*}{ Leaf No. } & Mean & 20.10 & 12.00 & 13.00 & 9.00 \\
\hline & \multirow{2}{*}{ Range } & 2.00 & 3.00 & 2.00 & 7.00 \\
\hline & & $14.0-16.0$ & $11-14$ & $12-14$ & $7-14$ \\
\hline \multirow{3}{*}{ Total soluble solids } & Mean & 15.24 & - & - & - \\
\hline & \multirow{2}{*}{ Range } & 2.00 & - & - & - \\
\hline & & $14.0-16.0$ & - & - & - \\
\hline
\end{tabular}

internodes length. On the other hand, the internodes number was the highest in the variety Hinds Special and the lowest in other varieties. The leaf length, width and number were the highest in Hinds Special variety and the lowest in U.S. 57-118-4 variety. Mean of total soluble solids were 15.24 in Hinds Special variety. However, in the other varieties did not enable to record, because the stalk width was very thin. It could be concluded that Hends special variety overpassed the other varieties with respect the studied traits.

U.S.57-118-4 variety was the highest range in stalk length. However, S.E.S.90 and Saccharum spontaneum varieties were the lowest range. In addition, the width of Hinds Special variety was the highest range and the other varieties were the lowest range.
The internodes length was the highest range in Hinds Special and S.E.S.90 varieties. However, it is the lowest in Saccharum spontaneum and U.S. 57-118-4 varieties.

S.E.S.90 variety was the highest range of internodes number. However, the other varieties were the lowest range. On the other hand, U.S. 57-118-4 variety was the higher range of leaf length and the other varieties were the lowest range.

U.S.57-118-4 variety was the highest range, however, the other varieties were the lowest range.

The results in table (4) indicate that the temperature degrees and relative humidity from March 2005 to June 2006. It is clear that the temperature degrees were descendingly decreased from December till February and were ascendingly increased until August. The 
Table 2. Correlation coefficient between any two of nine characters in four American wild cane varieties of stalk length of plant crop for 2005/2006 season in Sabahia Research Station at Alexandria, Egypt

\begin{tabular}{|c|c|c|c|c|c|c|c|c|}
\hline \multirow[b]{2}{*}{$\begin{array}{c}\text { Character and wild } \\
\text { varieties }\end{array}$} & \multirow{2}{*}{$\begin{array}{c}\text { Stalk } \\
\text { Width } \\
\text { cm } \\
x_{1} \\
\end{array}$} & \multirow[b]{2}{*}{$\begin{array}{c}\text { Tillers } \\
\text { No. } \\
\mathbf{x}_{2}\end{array}$} & \multicolumn{2}{|c|}{ Internodes } & \multicolumn{3}{|c|}{ Leaf } & \multirow[b]{2}{*}{$\begin{array}{c}\text { T.S.S } \\
\mathbf{x}_{8}\end{array}$} \\
\hline & & & $\begin{array}{c}\text { Length } \\
\mathbf{c m} \\
x_{3}\end{array}$ & $\begin{array}{c}\text { No. } \\
\mathbf{x}_{4}\end{array}$ & $\begin{array}{c}\text { Length } \\
\mathbf{c m} \\
x_{5} \\
\end{array}$ & $\begin{array}{c}\text { Width } \\
\text { cm } \\
x_{6}\end{array}$ & $\begin{array}{l}\text { No. } \\
\mathbf{x}_{7}\end{array}$ & \\
\hline \multicolumn{9}{|l|}{ Hinds Special: } \\
\hline Y Stalk length & 0.457 & - & $0.659 *$ & $0.725^{*}$ & 0.025 & 0.075 & $0.640 *$ & -0.459 \\
\hline $\mathrm{X}_{1}$ Stalk width & - & - & 0.488 & 0.358 & 0.344 & 0.314 & 0.245 & -0.485 \\
\hline $\mathrm{X}_{2}$ Tillers No. & - & - & - & - & - & - & - & - \\
\hline $\mathrm{X}_{3}$ Internodes L. & - & - & - & 0.475 & $-0.677^{*}$ & 0.028 & 0.355 & 0.124 \\
\hline $\mathrm{X}_{4}$ Internodes No. & - & - & - & - & 0.238 & 0.121 & $0.724 *$ & 0.365 \\
\hline $\mathrm{X}_{5}$ Leaf length & - & - & - & - & - & -0.426 & 0.189 & -0.430 \\
\hline $\mathrm{X}_{6}$ Leaf width & - & - & - & - & - & - & 0.166 & -0.528 \\
\hline $\mathrm{X}_{7}$ Leaf No. & - & - & - & - & - & - & - & 0.139 \\
\hline $\mathrm{X}_{8}$ T.S.S. & - & - & - & - & - & - & - & - \\
\hline \multicolumn{9}{|l|}{ S.E.S.90: } \\
\hline$\overline{\text { Y Stalk length }}$ & 0.375 & 0.186 & -0.288 & -.375 & -0.250 & 0.567 & -0.375 & - \\
\hline $\mathrm{X}_{1}$ Stalk width & - & 0.000 & 0.063 & 0.200 & 0.250 & 0.128 & 0.200 & - \\
\hline $\mathrm{X}_{2}$ Tillers No. & - & - & 0.059 & 0.229 & 0.186 & 0.449 & 0.172 & - \\
\hline $\mathrm{X}_{3}$ Internodes L. & - & - & - & - & 0.512 & -0.369 & -0.256 & - \\
\hline $\mathrm{X}_{4}$ Internodes No. & - & - & - & - & 0.000 & 0.206 & $1.000 * *$ & - \\
\hline $\mathrm{X}_{5}$ Leaf length & - & - & - & - & - & 0.181 & 0.000 & - \\
\hline $\mathrm{X}_{6}$ Leaf width & - & - & - & - & - & - & 0.206 & - \\
\hline$X_{7}$ Leaf No. & - & - & - & - & - & - & - & - \\
\hline $\mathrm{X}_{8}$ T.S.S. & - & - & - & - & - & - & - & - \\
\hline \multicolumn{9}{|l|}{ Saccharum spontaneum: } \\
\hline Y Stalk length & 0.331 & 0.179 & 0.392 & 0.000 & $0.658 *$ & 0.462 & 0.000 & - \\
\hline $\mathrm{X}_{1}$ Stalk width & - & 0.259 & 0.167 & $0.791 * *$ & 0.527 & 0.297 & $0.791 * *$ & - \\
\hline $\mathrm{X}_{2}$ Tillers No. & - & - & -0.220 & 0.000 & 0.176 & -0.446 & 0.000 & - \\
\hline $\mathrm{X}_{3}$ Internodes L. & - & - & - & -0.264 & 0.287 & 0.297 & -0.264 & - \\
\hline $\mathrm{X}_{4}$ Internodes No. & - & - & - & - & 0.000 & 0.118 & $1.000 * *$ & - \\
\hline $\mathrm{X}_{5}$ Leaf length & - & - & - & - & - & 0.121 & 0.000 & - \\
\hline $\mathrm{X}_{6}$ Leaf width & - & - & - & - & - & - & 0.118 & - \\
\hline $\mathrm{X}_{7}$ Leaf No. & - & - & - & - & - & - & - & \\
\hline $\mathrm{X}_{8}$ T.S.S. & - & - & - & - & - & - & - & \\
\hline \multicolumn{9}{|l|}{ S.E.S.90: } \\
\hline$\overline{\text { Y Stalk length }}$ & 0.137 & 0.012 & 0.046 & 0.377 & $0.814 * *$ & 0.420 & 0.237 & - \\
\hline $\mathrm{X}_{1}$ Stalk width & - & -0.329 & 0.527 & 0.459 & -0.524 & 0.010 & 0.150 & - \\
\hline $\mathrm{X}_{2}$ Tillers No. & - & - & 0.038 & -0.003 & 0.157 & 0.007 & -0.388 & - \\
\hline $\mathrm{X}_{3}$ Internodes L. & - & - & - & 0.181 & 0.041 & -0.212 & -0.243 & - \\
\hline $\mathrm{X}_{4}$ Internodes No. & - & - & - & - & $-0.721 *$ & 0.108 & 0.177 & - \\
\hline $\mathrm{X}_{5}$ Leaf length & - & - & - & - & - & 0.132 & -0.255 & - \\
\hline $\mathrm{X}_{6}$ Leaf width & - & - & - & - & - & - & 0.000 & - \\
\hline $\mathrm{X}_{7}$ Leaf No. & - & - & - & - & - & - & - & - \\
\hline $\mathrm{X}_{8}$ T.S.S. & - & - & - & - & - & - & - & - \\
\hline
\end{tabular}


Table 3. Correlation coefficient between any two of four wild American cane varieties of the certain characters during 2005/2006 at Sabahia Research Station, Alexandria, Egypt

\begin{tabular}{|c|c|c|c|c|c|c|c|c|}
\hline & S.W. & T. No. & Int. L & Int. No. & L.L. & L.W. & L. No. & T.S.S. \\
\hline Y Stalk length & 0.250 & $0.737 *$ & $0.866 * *$ & 0.575 & $0.760 *$ & $0.862 * *$ & $0.728 *$ & - \\
\hline $\mathrm{X}_{1}$ Stalk width & - & $0.729 *$ & $0.953 * *$ & $0.991 * *$ & $0.890 * *$ & $0.940 * *$ & $0.862 * *$ & - \\
\hline $\mathrm{X}_{2}$ Tillers No. & - & - & -0.560 & $0.996 * *$ & $-0.743 *$ & 0.175 & -0.354 & - \\
\hline $\mathrm{X}_{3}$ Internodes L. & - & - & - & $0.922 * *$ & $0.905^{* *}$ & $0.96 * *$ & $0.837 * *$ & - \\
\hline $\mathrm{X}_{4}$ Internodes No. & - & - & - & - & $0.915 * *$ & $0.966 * *$ & $0.907 * *$ & - \\
\hline $\mathrm{X}_{5}$ Leaf length & - & - & - & - & - & 0.078 & $0.950 * *$ & - \\
\hline $\mathrm{X}_{6}$ Leaf width & - & - & - & - & - & - & $0.950 * *$ & - \\
\hline $\mathrm{X}_{7}$ Leaf No. & - & - & - & - & - & - & - & - \\
\hline $\mathrm{X}_{8}$ T.S.S. & - & - & - & - & - & - & - & - \\
\hline \multicolumn{9}{|l|}{$\begin{array}{ll}* & 0.666 \\
* * & 0.798\end{array}$} \\
\hline 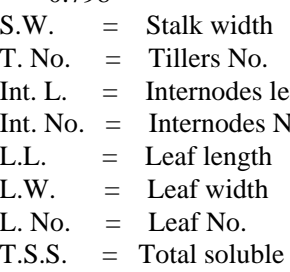 & & & & & & & & \\
\hline
\end{tabular}

Table 4. Temperature degrees and relative humidity from 2005 to 2006 seasons at Sabahia Research Station at Alexandria, Egypt

\begin{tabular}{|c|c|c|c|c|c|c|c|c|c|}
\hline \multirow{3}{*}{ No. } & \multirow{3}{*}{ Month } & \multicolumn{4}{|c|}{ Temperature degrees } & \multicolumn{4}{|c|}{ Relative humidity } \\
\hline & & \multicolumn{2}{|c|}{ Average of } & \multirow{2}{*}{ Mean } & \multirow{2}{*}{ Range } & \multicolumn{2}{|c|}{ Average of } & \multirow{2}{*}{ Mean } & \multirow{2}{*}{ Range } \\
\hline & & Max. & Min. & & & Max. & Min. & & \\
\hline 1 & March 2005 & 21.8 & 12.2 & 17.1 & 9.6 & 95.0 & 57.0 & 76.0 & 38.0 \\
\hline 2 & April & 23.7 & 13.3 & 18.5 & 10.4 & 99.0 & 56.0 & 77.0 & 43.0 \\
\hline 3 & May & 28.5 & 15.9 & 22.2 & 12.6 & 99.0 & 57.0 & 78.0 & 42.0 \\
\hline 4 & June & 30.1 & 19.5 & 24.8 & 10.6 & 99.0 & 64.0 & 82.0 & 35.0 \\
\hline 5 & July & 32.3 & 21.5 & 26.9 & 10.8 & 100.0 & 64.0 & 82.0 & 36.0 \\
\hline 6 & August & 32.8 & 23.1 & 28.0 & 9.7 & 89.0 & 58.0 & 73.0 & 31.0 \\
\hline 7 & September & 33.1 & 20.7 & 26.7 & 12.4 & 97.0 & 57.0 & 77.0 & 40.0 \\
\hline 8 & October & 27.7 & 17.4 & 22.5 & 10.3 & 96.0 & 61.0 & 78.0 & 35.0 \\
\hline 9 & November & 24.0 & 13.3 & 18.6 & 10.7 & 97.0 & 59.0 & 78.0 & 38.0 \\
\hline 10 & December & 20.0 & 10.0 & 17.9 & 10.0 & 97.8 & 60.0 & 78.8 & 37.8 \\
\hline 11 & January 2006 & 18.1 & 8.8 & 13.4 & 9.3 & 100.0 & 73.0 & 87.0 & 17.0 \\
\hline 12 & February & 20.1 & 8.8 & 14.5 & 11.3 & 98.0 & 67.0 & 82.0 & 31.0 \\
\hline 13 & March & 22.3 & 11.3 & 16.8 & 11.0 & 99.0 & 53.0 & 76.0 & 46.0 \\
\hline 14 & April & 26.2 & 14.5 & 20.3 & 11.8 & 98.1 & 56.0 & 77.0 & 42.1 \\
\hline 15 & May & 27.9 & 14.8 & 21.4 & 13.1 & 100.0 & 61.0 & 80.0 & 39.0 \\
\hline 16 & June & 31.1 & 19.9 & 25.5 & 11.2 & 100.0 & 62.0 & 81.0 & 38.0 \\
\hline
\end{tabular}

- Monthly Agricultural Meteorology from 2005 to 2006 seasons, Agriculture Research Centre, Giza, Cairo.

minimum of the relative humidity was in April and March while the maximum was at July, January and May.

The previous variance in the environmental conditions affects the growth of wild cane varieties, subsequently, reflects on the morphological, physiological and chemical processes, which yield to differing of agronomic or cultural characteristics as flowering dates, crossing (in open pollination), seedling numbers and other tested criteria.
The prior differences were due to the variation between varieties and the interaction between these varieties and climatic conditions.

The above results are in agreement with Gaber et al. 1981a, 1981b, 1990a and 1990b who concluded that means and ranges were varied with the variation between varieties or samples or the environmental conditions. 
Table (2) shows the simple correlation coefficients between stalk length and width, internodes length, internodes number, leaf length; width and number, and tillers number for Hinds Special, S.E.S.90, Saccharum spontaneum and U.S.57-118-4 varieties of wild cane with the exception of tillers number for the Hind Special variety, respectively.

\section{Hinds Special:}

The correlation between stalk length and internodes length, internodes number and leaf number was positive and significant as well as between internodes number and leaf number. However, it was negative and significant between internodes length and leaf length. On the other hand, the other correlations were not significant.

\section{S.E.S.90:}

The correlation between the internodes number and leaf number was positive and highly significant. While between the other characters were not significant.

\section{Saccharum spontaneum:}

The correlation between stalk width and internodes number, and leaf number was positive and highly significant as between stalk width and leaf numbers as well as between internodes number and leaf number. However, it was positive and significant between stalk length and leaf length. The other correlations were not significant.

\section{U.S.57-118-4:}

The correlation between stalk length and leaf length was positive and highly significant. However, the other correlations were not significant.

Table (3) shows the correlation coefficients between any two of four wild cane varieties of nine characteristics for 2005/2006 season.

The correlation between Hinds Special, S.E.S.90, Saccharum spontaneum and U.S.57-118-4, respectively were positive and highly significant for internodes length, leaf width. While, it was positive and significant between stalk length and tillers number, leaf length and number.

On the other hand, it was positive and highly significant between stalk width and internodes length, internodes number, leaf length and width, and number. As well as between internodes length and internodes number, leaf length, width and number as between internodes number and leaf length, width and number as well as between leaf length and leaf number as between leaf width and number.

However, it was negative and significant between tillers number and leaf length. The other correlations were not significant.
The preceding results are agreement with Gaber et al. 1981a, 1981b, 1990a and 1990b who found that the correlation between the plant weight and stalk length, plant diameter and leaf number, and internodes number was positive and highly significant as well as between stalk length and plant diameter, and leaf number as between plant diameter and leaf number. While, it was positive and significant between plant leaf number and internodes number. The other correlations were not significant.

Also, they concluded that sugarcane varieties were varied in the significant of correlations for the agronomical and physiological characters.

The obtained results seem to add more support to the finding of Nour et al. (1977) who indicated that highly positive correlation between stalk weight and stalk length, internodes number and stalk diameter, as well as between stalk length and internodes number, also, between internodes number and diameter. However, correlation between other characters were not significant.

\section{RE FERENCES}

Anon (1959). HSPA. Sugar Manual, Honolulu, Hawaii.

Anon (2008). Annual Conference of Egyptian Society Sugar Technologists, 39, pp. 9-13.

Gaber, A.A.; H.A. Mesbah; A.H. Nour and M.A. Abd ElRassol (1981a). Correlation between yield and some morphological, physiological, chemical characters and borers infestation in thirty-four varieties of sugarcane at Alexandria. Agric. Res. Rev., 59(8): 99-112, Ministry of Agriculture.

Gaber, A.A.; H.A. Mesbah, M.A. El-Manhally and A.H. Nour (1981b). Relationship between number of tillers, sugar content and levels of borers infestation of some sugarcane varieties. Agric. Res. Rev., 59(8): 113-126, Ministry of Agriculture.

Gaber, A.A.; M.A. Farg and M.F. Abou El-Fattah (1990a). Relationship between plant weight and some agronomic characters in the plant crop and first ratoon of eight sugarcane varieties at Alexandria. Com. Sci. and Dev. Res., vol. 31: 55-82.

Gaber, A.A.; Samia, S. El-Maghraby, M.H. El-Deeb, Fauzia, H. El-Helbawi and M.F. Abou El-Fatth (1990b). Correlation between stalk weight and some morphological characters in the plant crop and first ratoon of some sugarcane varieties at Alexandria. Annals of Agriculture Science, Moshtohor, Vol. 28, No. (4): 1947-1973.

Nour, A.H., T.M. Fayed, F.M. Abdel-Ghaffar, M.K. Adawi and A.K.A. Selim (1977). Analysis of yield components in sugarcane. Agric. Res. Rev., 55: 167-174, Ministry of Agriculture.

Snedecor, G.W. and W.G. Cochran (1971). Statistical methods. $6^{\text {th }}$ ed. Iowa State University Press, Iowa, U.S.A. 


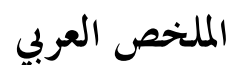

\section{العلاقة بين طول الساق وبعض الصفات الزراعية فى بعض أصناف القصب الغرس البرية

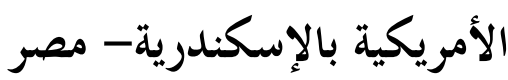

$$
\text { عبد الحميد عبد الحميد جابر، محمد فوزى أبو الفتح }
$$

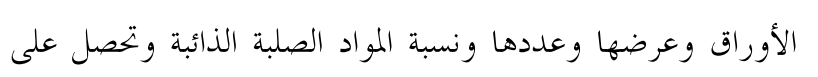

$$
\text { النتائج التالية:- - الت وعرضن }
$$

1- اختلفت الصفات التي تحت الدراسة باختلاف الأصناف وكان

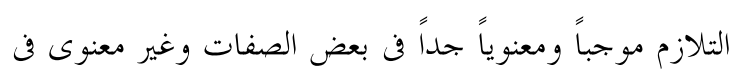

$$
\text { بعض الصفات الأخرى. }
$$

ץ- وجد أن التلازم ما بين أى صنفين من الأربعة أصناف التى

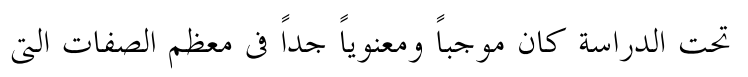

$$
\text { تم دراستها. ت تحت }
$$

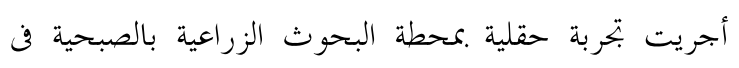

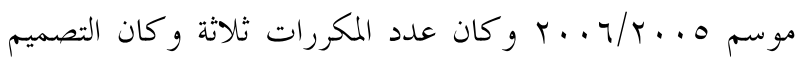

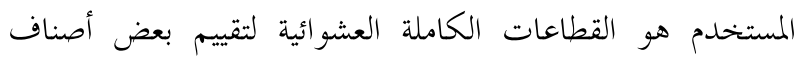

القصب البرية الأمريكية وكانت الأصناف المستخدمة هى:

Hinds Specia, S.E.S.90, Saccharum spontaneum and U.S.57-118-4.

ولقد تم أخذ عشرة سيقان عشو ائياً بعد كسرها من كل قطعة

تحريبية بعد تطويشها عند هاية فترة التزهير لدراسة العلاقة ما بين

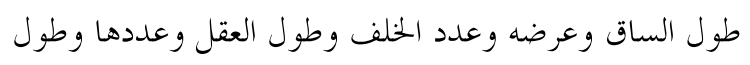

